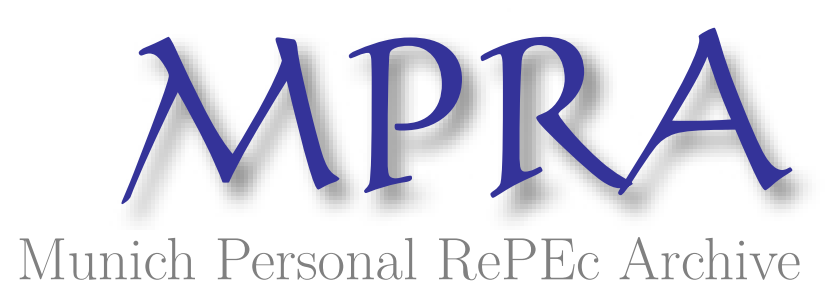

\title{
The Relationship Conflict between Venture Capital and Entrepreneur
}

\author{
Alqatawni, Tahsen \\ Walden University
}

3 July 2013

Online at https://mpra.ub.uni-muenchen.de/48005/

MPRA Paper No. 48005, posted 05 Jul 2013 04:16 UTC 
The Relationship Conflict between Venture Capital and Entrepreneur

By

Tahsen Alqatawni 


\begin{abstract}
The dilemmas that may encounter entrepreneurship result of an expected conflict between VCs and entrepreneur, disagreement can be beneficial for the venture performance. While the conflicts classified as personal disagreement, which negatively associated with entrepreneur's performance. In this paper, after the author reviewed the literature studies that involve the entrepreneur and venture capital, related domains of research into relationships between both. There is a significant gap in research, which focus on possible resolution of relationship conflict between the entrepreneurs and venture capital.
\end{abstract}




\section{The Relationship Conflict between VCs and Entrepreneur}

The positive relationship between the venture capital and entrepreneur are highly significant, which make both of them mutually symbiotic, and trying their best to maximize the business value. In addition, the positive relations raising the development of high growth businesses that create jobs and create wealth that potential to contribute to the economy. The dilemmas that may encounter entrepreneurship result of an expected conflict between VCs and entrepreneur, disagreement can be beneficial for the venture performance. While the conflicts classified as personal disagreement, which negatively associated with entrepreneur's performance.

There is a critical relationship between the entrepreneurs and venture capitalists, which could be a meeting of minds or clash of heads (Proimos, 2006). Zacharakis, Erikson, and George (2010), stated the current study finds relation conflict between venture capitalist and entrepreneur leads to reduced confidence in partner cooperation while the classical study views task conflict favorably. However, the VCs - entrepreneur partnership involve conflicts, due to different goals and objectives towards the business. In addition, "the venture capital partnership often suffers from lacking communication from either or both parties, which could start or worsen the conflict" (Li, 2011).

The relationship conflict can lead to serious problems; can cause costly mistakes and business failures, while entrepreneurs engaged this conflict, they have a less time and energy to spend on working toward the business goals. Similarly, when entrepreneurs ignored a conflict a cause, the organization is in danger of ignoring dangers that could lead to serious harm (Collewaert, 2013). 


\section{Literature Review}

In 1755, the earliest definition of entrepreneurship wrote by Irish economist Richard Cantillon, used it as an economic title provide the details of the process of carrying the risk of buying at known prices and selling at unknown prices (Aspromourgos, 2012). The entrepreneur word derived from the French verb entreprendre, which mean, "to undertake" (Dana, 2011). The later definitions for an entrepreneur by Schultz (1980) that the person who deal with imbalance rather than deal with uncertainty. In addition, the modern entrepreneur is the person who holds a high position, in executives' level of operation decision, take charge of the right of operation decision and get hold of on the entrepreneur's risk in the business can be seen entrepreneur (Mao, 2010).

The venture capital (VCs) is a powerful equity financing resource that addresses the funding necessary of entrepreneurial businesses in particular in environments of uncertainty (Rosenbusch, 2012). Venture capital is one the most influential factor underlying the economic growth of some regions within the United States (Samila, 2011). The classical definition of VCs is a wealthy person or progressive financial institution that is willing to provide sufficient risk capital to appraise the specific opportunity and provide financial backing for its introduction to the market place (Charpie, 1967).

The dilemma of interaction conflict between the VCs and entrepreneur could leave a negative impact beyond both partners to the whole economy. However, in 2012, Lim study findings showed a direct relationship has no significant impact on conflict between the VC and entrepreneur; but the indirect relationship has a greater degree of conflict between the VC and entrepreneur. Collewaert (2013) stated that, the probability of conflict escalation could be causing a negative business issue such as failure or another type of forced exit, which represent 
the darker sides of the relationship between VCs and entrepreneurs. However, Brettel, Mauer, and Appelhoff (2013) argued that, the negative impact of relationship conflict might impede any positive influence of task conflict from happening. Consequently, the relationship conflict may not only harm the perspicacity value but also business performance.

Rosenbusch, Brinckmann, and Müller examined the theoretical proposals that the VC is a valuable source to develop the performance of funded firms, particularly in environments of uncertainty. In addition, the authors synthesized 76 experimental samples on 36,567 firms. Conversely, the found a small positive performance influences of VC backing on funded firm performance. However, the effect disappears if researchers control the business selection impacts. In addition, the study hypothesis focused on the relationship between VC backing and funded firm. Rosenbusch, Brinckmann, and Müller (2012) study findings there are a small positive performance influences of VC backing on funded firm. However, they noted that the effect disappears if researchers control the business selection impacts.

Zacharakis, Erikson, and George (2010) studied the conflict between the venture capitalists and entrepreneurs, and the impacts of conflict on confidence in a business partnership explored. The study found the relationship conflict had negatives prevail caused lower overall performance, whereas past researchers find that the viewpoint of venture capitalists on the conflict can favorably influence. While Brettel, Mauer, and Appelhoff (2012) argued that, the negative impact of relationship conflict may impede any positive influence of task conflict from happening. However, the relationship conflict may not only harm the investor value but also business performance. 
$\mathrm{Li}$ and Abrahamsson (2012) argued there is a gap of knowledge regarding conflicts between entrepreneurs and venture capitalists. Moreover, the venture capital partnership often suffers from lacking communication from either or both parties, which could start or worsen the conflict. However, Collewaert and Fassin (2013) founding the probability of conflict escalation could be causing a negative business outcome such as failure or another form of forced exit, which present the darker side of the relationship between VCs and entrepreneurs.

In 2011, Zhang study found that all entrepreneurs who had previous experience and high skills showed less relationship conflict, which appeared to raised more funding by venture capital. However, Chen, Yao, and Kotha (2009) conducted a laboratory experiment that consistently showed the entrepreneurial preparedness skill positively affected the VCs' decision. There is an urgent need for new research's includes practical strategies and activities, teaching the entrepreneur a conflict resolution procedures and skills to reduce the negative effects on business. The future researchers could also assess what entrepreneurs and VCs can do a prior to minimize possible conflict and build a solid partnership (Zacharakis, 2010).

In 2012, Yitshaki conducted a study about the relational norms by the entrepreneurs who increase the confidence in partnership with VCs. The study was one of the rare researches that suggested a possible resolution of relationship conflict between the entrepreneurs and VCs. In addition, the study had several implications for understanding the difficulty to the relationship. Yitshaki argued there are possible resolutions to these conflicts can be use by several thoughts of the venture and the contractual arrangements. The study suggested that both entrepreneurs and venture capitals, it would occasionally restore relational standards in order to determine perceptual asymmetries and set up expectations for long-term relationship. Venture capitals need to clarify their expectations and common interests, thereby increasing 
entrepreneurs' faith in partnership. A high level of co-operation during crises; It might contribute to entrepreneurs' commitment to changes in leadership in a way that might reduce their uncertainty and build up their confidence in cooperation.

\section{Future Directions}

The future studies should consider the potential resolution of relationship conflict between the entrepreneurs and VCs, proposing solutions and examine it. It is necessary to understand and apply various conflict resolution techniques, which clearly an urgent need for such assumption, package of proposals, or communication tool that can be implemented to consolidate the relationship between the parties. There is a need to examine the significant effect of the degree of VCs conflict resolution skills and training on the corporation, which would explain the degree of urgent need to enhance these skills through the education.

Obviously, the purpose of the future research has the potential to reach the optimal outcome for the chosen topic. All these studies show a positive impact on the probability of successful implementation, which can have a significant impact of the study field. The potential impact of this study is to help researchers practice and deepen their understanding of the nature of the conflict and solutions, through entrepreneurship scholars to outline and debate research opportunities within the field of the relationship conflict between VCs and entrepreneur. 


\section{Summary}

There is a critical relationship between the entrepreneurs and venture capitalists, which make both mutually symbiotic, and trying their best to maximize the business value. Because of different interests or mismanagement, that would create conflict over the relationship between

both parties. Anyhow, the conflict of relationship between both parties leads to reduced business venture or could go further causing a business failure. In addition, the negative effects may exceed both parties to the overall economy. However, after reviewed the literature studies that involve the entrepreneur and venture capital, there is an urgent need to conduct more in-depth new studies to understand of the nature of the conflict, and suggest possible solutions to this conflict. Furthermore, the study topic will enhance both entrepreneurs and VCs performance and help deepen their understanding of nature of the conflict. 


\section{Reference}

Aspromourgos, T. (2012). Entrepreneurship, risk and income distribution in Adam Smith. The European Journal of the History of Economic Thought, (ahead-ofprint), 1-20. doi:10.1080/09672567.2012.683025

Brettel, M., Mauer, R., \& Appelhoff, D. (2013). The entrepreneur's perception in the entrepreneur-VCF relationship: the impact of conflict types on investor value. Venture Capital, (ahead-of-print), 1-25. doi:10.1080/13691066.2013.782625

Charpie, R. A. (1967). Technological Innovation and Economic Growth. Applied Science and Technological Progress: A Report to the Committee on Science and Astronautics, US House of Representatives, 357.

Chen, X. P., Yao, X., \& Kotha, S. (2009). Entrepreneur passion and preparedness in a business plan presentations: a persuasion analysis of venture capitalists' funding decisions. Academy of Management Journal, 52(1), 199-214.

Collewaert, V., \& Fassin, Y. (2013). Conflicts between entrepreneurs and investors: The impact of perceived unethical behavior. Small Business Economics, 40(3), 635-649. doi:http://dx.doi.org/10.1007/s11187-011- 9379-7

Dana, L. P. (2011). World Encyclopedia of Entrepreneurship. Edward Elgar Publishing.

Li, J., \& Abrahamsson, J. T. (2011). New money, new problems: A qualitative study of the conflicts between venture capitalists and entrepreneurs in Sweden(Doctoral dissertation, Umeå University). Retrieved from http://umu.divaportal.org/smash/record.jsf?pid=diva2:426612 
Lim, K., \& Cu, B. (2012). The effects of social networks and contractual characteristics on the relationship between venture capitalists and entrepreneurs. Asia Pacific Journal of Management, 29(3), 573-596.doi:10.1007/s10490-010-9212-x

MAO, H. Y., \& Ge, H. (2010). The situation and existent problem of entrepreneur group construction of China. Management Science and Engineering, 2(2), 31-35.Ritravid from http://www.cscanada.net/index.php/mse/article/view/836

Rosenbusch, N., Brinckmann, J., \& Müller, V. (2012). Does acquiring venture capital pay off for the funded firms? A meta-analysis on the relationship between venture capital investment and funded firm financial performance. Journal of Business Venturing. http://dx.doi.org/10.1016/j.jbusvent.2012.04.002

Proimos, A., \& Murray, W. (2006). Entrepreneuring into venture capital. The Journal of Private Equity, 9(3), 23-34. doi: 10.3905/jpe.2006.635426

Samila, S., \& Sorenson, O. (2011). Venture capital, entrepreneurship, and economic growth. The Review of Economics and Statistics, 93(1), 338-349. doi:10.1162/REST_a_00066

Schultz, T.W. (1980): Investment in entrepreneurial ability, Scandinavian Journal of Economics 82, pp. 437-448. Retrieved from http://www.jstor.org/discover/10.2307/3439676?uid=3739864\&uid=2134 \&uid=2\&uid=70\&uid=4\&uid=3739256\&sid=21102231552401

Zacharakis, A., Erikson, T., \& George, B. (2010). Conflict between the VC and entrepreneur: the entrepreneur's perspective. Venture Capital, 12(2), 109-126. doi:10.1080/13691061003771663 
Yitshaki, R. (2012). Relational norms and entrepreneurs' confidence in venture capitalists' cooperation: the mediating role of venture capitalists' strategic and managerial involvement. Venture Capital, 14(1), 43-59.doi:10.1080/13691066.2012.662839 